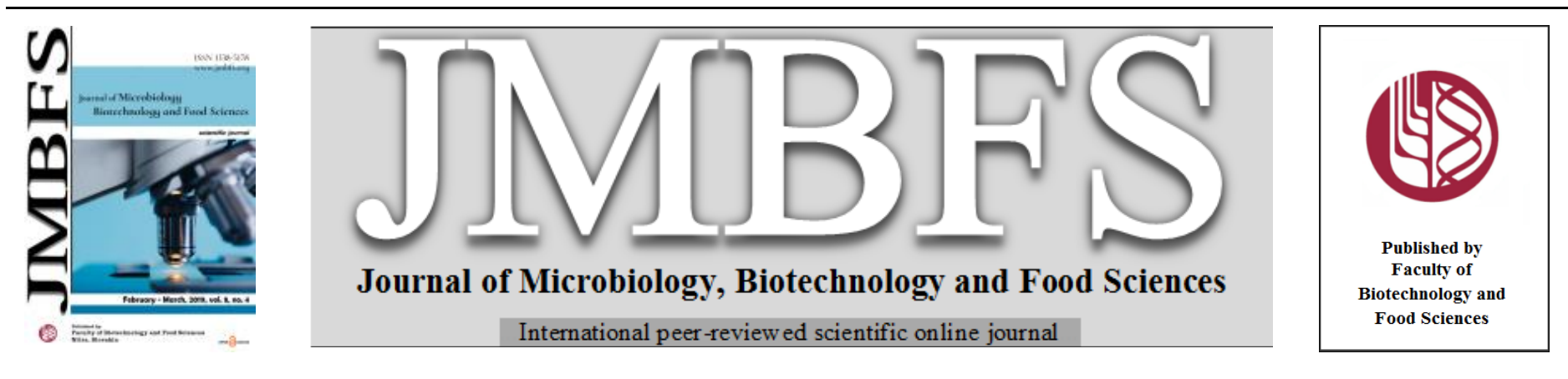

\title{
DEVELOPMENT AND EVALUTATION OF YOGURT SUPPLEMENTED WITH LENTIL FLOUR
}

\section{Faizan ul Haq ${ }^{1}$, Aysha Sameen ${ }^{1}$, Qamar u Zaman ${ }^{1}$, Bilal Sajid Mushtaq ${ }^{1}$, Muhammad Bilal Hussain*2, Ahsan Javed ${ }^{2}$, Sergey Plygun $^{3,4,5}$, Olga Korneeva ${ }^{6}$, Mohammad Ali Shariati ${ }^{3,4}$}

\author{
Address(es): \\ ${ }^{1}$ National Institute of Food Science and Technology, University of Agriculture Faisalabad, Pakistan. \\ ${ }^{2}$ Institute of Home and Food Sciences, Government College University, Faisalabad. \\ ${ }^{3}$ Researcher, Laboratory of Biocontrol and Antimicrobial Resistance, Orel State University named after I.S. Turgenev, Orel, Russia. \\ ${ }^{4}$ All Russian Research Institute of Phytopathology, Moscow Region, Russia. \\ ${ }^{5}$ European Society of Clinical Microbiology and Infectious Diseases, Basel, Switzerland. \\ ${ }^{6}$ Researcher, Doctor of Biological Sciences, Voronezh State University of Engineering Technologies, Voronezh, Russia.
}

*Corresponding author: itsmee1919@gmail.com

doi: 10.15414/jmbfs.2019.8.4.1005-1009

\section{ARTICLE INFO}

Received 23. 8. 2018

Revised 14.11. 2018

Accepted 20.11. 2018

Published 1. 2. 2019

Regular article

OPEN $\partial_{\text {ACCESS }}$

\begin{abstract}
Yogurt is well known and most consumed fermented dairy product due to its health promoting effects and better sensory attributes, but consumers' demand the value added foods with least defects and more nutrition. Different naturally occurring foods like fruits and lentils have been supplemented in yogurt to enhance the physic-chemical, nutritional and sensorial attributes. In this research milk was supplemented with $1 \%, 2 \%, 3 \%$ and $4 \%$ lentil (Lens culinaris) flour (LF) for development of lentil yogurt; $\mathrm{LY}_{0}\left(0 \%\right.$ lentil), $\mathrm{LY}_{1}(1 \%$ lentil), $\mathrm{LY}_{2}$ (2\%lentil), $\mathrm{LY}_{3}$ (3\% lentil) and $\mathrm{LY}_{4}$ (4\% lentil). The proximate composition of LY included; total solids (TS), solid not fat, crude fat, moisture, crude fiber, ash nitrogen free extract (NFE) and crude protein. While during storage of 28 days at $4 \pm 1^{\circ} \mathrm{C} \mathrm{pH}$, acidity, water holding capacity, viscosity, synersis and sensory evaluation were recorded to assess the effect of lentil flour on its physicchemical and sensorial improvement. The proximate composition of LY revealed that as the LF proportion was increased the nutritional profile; mineral contents and protein, was also improved significantly $(\mathrm{p}<0.01)$. There was significant $(\mathrm{p}<0.01)$ increase in resistance of change of $\mathrm{pH}$ and acidity of LY as compared to control. Similarly, LF had highly significant effect on synersis, water holding capacity and viscosity $(\mathrm{p}<0.01)$ due to the presence of complex carbohydrates and glycoprotein. Moreover, the sensory evaluation was considerably improved and LY containing $2 \%$ LF stood out to be the best sample of LY. Considering outcomes of all the parameters, it is suggested that lentil flour can serve as potential supplement for the value addition of yogurt and other fermented dairy products.
\end{abstract}

Keywords: Lentil yogurt, viscosity, water holding capacity, synersis

\section{INTRODUCTION}

The dairy industry has definitely supreme importance in the food sector. Fermented milk products are well-known globally and have been consumed for hundreds of years. The production of novel varieties of yogurt is relatively new idea if we keep in vision that how faster latest technologies are being advanced from year to another. Yogurt has become unique product as its demand is continually increasing in the market due to consumers' approval for a superior standard of living that involves more nutritious food-stuffs (Codina et al., 2016) Yogurt is a product, that is prepared in response to the LAB activity causing the milk to ferment, nutritionally it has same value in comparison to the milk, but in yogurt the concentration of nutrients is more (Wang et al., 2013) and the digestibility of these nutrients is also better (Gaetke et.al., 2010). Yogurt is preferred globally because of its ability to reduce the disorders related to nervous, cardiovascular and gastrointestinal systems (Crichton et al., 2011; SoedamahMuthu et al., 2011). According to Ozen and Kilic (2009) consumers are concerned with yogurt not only due to the health promoting effects and nutritional benefits but they are also attracted to its texture, appearance and taste as well. Lee and Lucey (2010) confirmed the statement that the physical appearance and texture directly determines the consumers' attraction to yogurt like better viscosity and lesser synersis. Penna et al. (2006) added the other textural and physio chemical characters like acidity, aroma, texture and appearance. However, there are plenty of different problems associated with the sensory and physical properties which hinder the consumer's preference for yogurt. To enhance these physical and sensory attributes the yogurt is incorporated with different stuffs like fruits, pulses, chocolate, grains and nuts (Kucukcetin et al., 2012). Some important leguminous pulses incorporated in yogurt for its physic-chemical development are lentils (Agil $\boldsymbol{e t}$ al., 2013; Zare $\boldsymbol{e t}$ al., 2011), chickpeas, peas, (Zare et al., 2012, 2013), beans and quinoa. Supplementing a pulse like lentil in the form of flour in yogurt preparation can improve its quality attributes especially from nutritional point of view. Numerous studies have focused on beneficial components of lentil flour (Agil et al., 2013; Zou et al., 2011).

Lentil (Lens culinaris) is being acknowledged progressively because of its nutrients profile (Zou et al., 2011) and also keeping the compositional attributes under consideration as it has notable content of carbohydrates, fatty acid fiber and protein (Boye et al., 2010). There is significant content of complex carbohydrates in lentil like raffinose, inulin and fructo-oligosaccharides which assist the growth of probiotics in fermented milk products, termed as prebiotics (Zare et al., 2012).

Keeping all these attributes in view the current research work was planned, focusing on evaluation of effects due to supplementing lentil flour on physiochemical, textural, sensory quality and shelf life of yogurt, like other legumes lentil is also a nutrient rich source having significant amount of raffinose, inulin and other oligosaccharides that have prime importance in promoting functionality and growth of beneficial bacteria. Also the protein profile increases the total solids of final product that could serve as agent to reduce the synersis and increase the firmness and viscosity of yogurt.

\section{MATERIAL AND METHODS}

\section{Procurement and Analysis of Raw material}

Red lentils and chemical reagents were obtained from market. Buffalo milk was purchased from University Dairy farm, University of Agriculture, Faisalabad. Physic-chemical analysis of milk $(\mathrm{pH}$, acidity, moisture, fat, protein, solids not fat and total solids) and lentil flour (Moisture, crude fat, crude protein, ash, crude fiber Nitrogen free extract) were performed for the determination of proximate composition by following the methods described in AOAC (2012). 


\section{Lentil-Yogurt Preparation}

Yogurt was prepared by following the method of Kaur et al.(2017) with the addition of $0 \%, 1 \%, 2 \%, 3 \%$ and $4 \%$ lentil (parched) flour to make treatments: $\mathrm{LY}_{0} \mathrm{LY}_{1}, \mathrm{LY}_{2}, \mathrm{LY}_{3}$ and $\mathrm{LY}_{4}$ respectively.

\section{Physic-chemical analysis of Lentil- Yogurt}

Different chemical analysis (moisture, $\mathrm{pH}$, acidity, crude fat, crude protein, ash, SNF and total solids) of LY were carried out by using the methods of AOAC (2012).

\section{Apparent viscosity}

Apparent viscosity of yogurt was measured by following the method described by Sodini et al. (2005) using spindle no. 4 of viscometer at $60 \mathrm{rpm}$ for $15 \mathrm{sec}$. against $100 \mathrm{ml}$ of yogurt sample.

\section{Synersis}

Synersis was measured by the method adopted by Amatayakul et al. (2006).

\section{Water holding capacity (WHC)}

Water holding capacity of LY was assessed in accordance with the method from Sodini et al. (2005)

\section{Sensory analysis}

Sensory evaluation of lentil flour supplemented yogurt was carried out by using methods described by Meilgaard et al. (2007).

\section{Statistical analysis}

Data acquired was subjected to appropriate statistical tools to detect the level of significance as described by Steel et al. (1997).

\section{RESULTS AND DISCUSSION}

\section{Subheadings should be used}

\section{Raw material analysis}

The proximate composition of milk and lentil powder is mentioned in the table: 1 , which indicates the percentage means of all proximate components of lentil flour; moisture, crude fat, ash, protein, fiber and NFE 8.45 $\pm 0.06,1.86 \pm 0.25$ $3.37 \pm 0.06,26.61 \pm 1.26,8.03 \pm 0.11$ and $51.68 \pm 1.25$ respectively. Proximate of milk are; moisture, fat, ash, protein, SNF, TS, LR, pH, and acidity; $86.48 \pm 0.12$, $4.12 \pm 0.10,0.90 \pm 0.03,4.21 \pm 0.28,9.29 \pm 0.36,13.52 \pm 0.12,23.67 \pm 0.58,6.55 \pm 0.07$ and $0.18 \pm 0.02$ respectively.
Table1 Raw material analysis results

\begin{tabular}{lcc}
\hline Constituent & $\begin{array}{c}\text { Lentil Flour } \\
(\text { means })\end{array}$ & Milk (means) \\
\hline Moisture (\%) & $8.45 \pm 0.06$ & $86.48 \pm 0.12$ \\
\hline Crude fat (\%) & $1.86 \pm 0.25$ & $4.12 \pm 0.10$ \\
\hline Ash (\%) & $3.37 \pm 0.06$ & $0.90 \pm 0.03$ \\
\hline Crude protein (\%) & $26.61 \pm 1.26$ & $4.21 \pm 0.28$ \\
\hline Crude fiber (\%) & $8.03 \pm 0.11$ & - \\
\hline NFE (\%) & $51.68 \pm 1.25$ & - \\
\hline Solids not Fat (SNF) & - & $9.29 \pm 0.36$ \\
\hline Total solids & - & $13.52 \pm 0.12$ \\
\hline Lactometer reading & - & $23.67 \pm 0.58$ \\
\hline pH & - & $6.55 \pm 0.07$ \\
\hline Acidity & - & $0.18 \pm 0.02$ \\
\hline
\end{tabular}

It is clearly demonstrated that there were notable variations in the compositiona attributes of both raw materials. Moisture $(86.48 \pm 0.12)$ content of raw milk was found to be higher than that of lentil flour $(8.45 \pm 0.06)$. That is evident of shorter shelf life of milk as compared to lentils'. The results are within the range elaborated by Takruri and Issa (2013). Nitrogen free extract in lentil flour $(51.68 \pm 1.25)$ is in accordance with the outcomes described by Kucukcetin et al. (2012).

\section{Proximate analysis of Lentil Yogurt}

The effect of lentil flour supplementation on moisture, crude fat, crude protein crude fiber, ash, solids not fat and total solids was highly significant $(\mathrm{p}<0.01)$. Moisture content was decreased in all respective samples of LY; $\mathrm{LY}_{0}$ showed the highest moisture content $(86.63 \pm 0.10)$ than $\mathrm{LY}_{1}(75.75 \pm 0.05 \%), \quad \mathrm{LY}_{2}$ (70.67 \pm 0.68$), \mathrm{LY}_{3}(68.93 \pm 2.63)$ and $\mathrm{LY}_{4}$ exhibited the lowest moisture content (65.49 \pm 0.69$)$ among all other samples. The similar decreasing trend was noticed in study performed by Yared, (2013). The trend of ash content was; $0.92 \pm 0.03$, $0.95 \pm 0.02 ; 0.96 \pm 0.07 ; 1.05 \pm 0.07$ and $1.09 \pm 0.08$ in al LY samples; $\mathrm{LY}_{0}, \mathrm{LY}_{1}, \mathrm{LY}_{2}$ $\mathrm{LY}_{3}$ and $\mathrm{LY}_{4}$ respectively. Similarly, the highest fiber was in $\mathrm{LY}_{4}(2.05 \pm 0.13)$ and the lower $(0.82 \pm 0.03)$ was in $\mathrm{LY}_{1}$ but control had no fiber in it. The highes protein content $(8.36 \pm 0.02)$ was highest in $\mathrm{LY}_{4}$ and other combinations also had more protein content $\left(5.81 \pm 0.34\right.$ in $\mathrm{LY}_{2}$ and $5.61 \pm 0.20$ in $\left.\mathrm{LY}_{1}\right)$ than contro $(3.92 \pm 0.18)$. The protein was increased by gradually enhancing the flour percentage in LY like that of moisture. It was evident that $\mathrm{LY}_{4}$ had highest fat content $(5.31 \pm 0.08)$ and other treatments also had more fat content $(5.12 \pm 0.22$ in $\mathrm{LY}_{3}, 4.98 \pm 0.12$ in $\mathrm{LY}_{2}$ and $4.55 \pm 0.13$ in $\left.\mathrm{LY}_{1}\right)$ than control $(4.36 \pm 0.12)$. The solids not fat were also positively affected by the LF incorporation; highest SNF were in $\mathrm{LY}_{4}(29.00 \pm 0.65)$ followed by $\mathrm{LY}_{3}(24.84 \pm 1.52), \mathrm{LY}_{2}(24.34 \pm 0.61), \mathrm{LY}$ $(19.70 \pm 0.08)$ and $\mathrm{LY}_{0}(9.00 \pm 0.21)$. Lentil flour addition in yogurt caused progressive increase in total solids $(\mathrm{p}<0.01)$, this increase in TS content of yogurt is definitely because of higher solids in lentil flour. Highest TS content was noticed in $\mathrm{LY}_{4}(34.30 \pm 0.61)$ followed by $\mathrm{LY}_{3}(30.09 \pm 2.45), \mathrm{LY}_{2}(29.33 \pm 0.68)$ $\mathrm{LY}_{1}(24.25 \pm 0.05)$ and control $(13.37 \pm 0.10)$. Results of current studies are in accordance with work performed by Yared, (2013).

Table 2 Proximate analysis of Lentil Yogurt

\begin{tabular}{|c|c|c|c|c|c|c|c|}
\hline \multirow[t]{2}{*}{$\mathbf{L Y}$} & \multicolumn{7}{|c|}{ Percentage Means \pm Standard deviation (SD) } \\
\hline & Moisture & Ash & Fat & Protein & Fiber & TS & SNF \\
\hline \multirow{2}{*}{$\mathrm{LY}_{0}$} & 86.63 & 0.92 & 4.36 & 3.92 & \multirow{2}{*}{$0^{\mathrm{d}}$} & 13.37 & 9.00 \\
\hline & $\pm 0.10^{\mathrm{a}}$ & $\pm 0.03^{\mathrm{a}}$ & $\pm 0.12^{\mathrm{b}}$ & $\pm 0.18^{\mathrm{c}}$ & & $\pm 0.10^{\mathrm{d}}$ & $\pm 0.21^{\mathrm{d}}$ \\
\hline \multirow[b]{2}{*}{$\mathrm{LY}_{1}$} & 75.75 & 0.95 & 4.55 & 5.61 & 0.82 & 24.25 & 19.70 \\
\hline & $\pm 0.05^{\mathrm{b}}$ & $\pm 0.02^{\mathrm{ab}}$ & $\pm 0.13^{\mathrm{b}}$ & $\pm 0.20^{\mathrm{b}}$ & $\pm 0.03^{\mathrm{c}}$ & $\pm 0.05^{\mathrm{c}}$ & $\pm 0.08^{\mathrm{c}}$ \\
\hline \multirow[b]{2}{*}{$\mathrm{LY}_{2}$} & 70.67 & 0.96 & 4.98 & 5.81 & 1.40 & 29.33 & 24.34 \\
\hline & $\pm 0.68^{\mathrm{c}}$ & $\pm 0.07^{\mathrm{ab}}$ & $\pm 0.12^{\mathrm{a}}$ & $\pm 0.28^{\mathrm{b}}$ & $\pm 0.03^{\mathrm{b}}$ & $\pm 0.68^{\mathrm{b}}$ & $\pm 0.61^{\mathrm{b}}$ \\
\hline \multirow{2}{*}{$\mathrm{LY}_{3}$} & 68.93 & 1.05 & 5.12 & 6.72 & 1.83 & 30.09 & 24.84 \\
\hline & $\pm 2.63^{\mathrm{cd}}$ & $\pm 0.07^{\mathrm{ab}}$ & $\pm 0.22^{\mathrm{a}}$ & $\pm 1.34^{\mathrm{ab}}$ & $\pm 0.17^{\mathrm{a}}$ & $\pm 2.45^{\mathrm{b}}$ & $\pm 1.51^{\mathrm{b}}$ \\
\hline \multirow{2}{*}{$\mathrm{LY}_{4}$} & 65.49 & 1.09 & 5.31 & 8.36 & 2.05 & 34.30 & 29.00 \\
\hline & $\pm 0.69^{\mathrm{d}}$ & $\pm 0.08^{\mathrm{b}}$ & $\pm 0.08^{\mathrm{a}}$ & $\pm 0.02^{\mathrm{a}}$ & $\pm 0.13^{\mathrm{a}}$ & $\pm 0.61^{\mathrm{a}}$ & $\pm 0.65^{\mathrm{a}}$ \\
\hline
\end{tabular}

$\mathrm{LY}_{0}\left(0 \%\right.$ lentil), $\mathrm{LY}_{1}$ (1\% lentil), $\mathrm{LY}_{2}$ (2\%lentil), $\mathrm{LY}_{3}$ (3\% lentil) and $\mathrm{LY}_{4}(4 \%$ lentil), TS; total solids, SNF; Solids not Fat.

Physic-chemical analysis of Lentil Yogurt:

\section{Effect on pH}

The changes in $\mathrm{pH}$ of LY are caused due to biochemical changes and microbial growth throughout the incubation and storage period. Statistical data shown that the $\mathrm{pH}$ of LY samples were highly significantly different $(\mathrm{p}<0.01)$ with lentil flour incorporation all the yogurts showed different $\mathrm{pH}$ throughout the storage period. The $\mathrm{pH}$ was decreased from 4.50 to $3.88 \pm 0.03,4.00 \pm 0.03,4.12 \pm 0.01$, $4.11 \pm 0.03$ and $4.13 \pm 0.03$ for $\mathrm{LY}_{0}, \mathrm{LY}_{1}, \mathrm{LY}_{2}, \mathrm{LY}_{3}$ and $\mathrm{LY}_{4}$ yogurt samples respectively. Consequences of present study were in line with the results revealed by Chen (2016). The rate of $\mathrm{pH}$ decline in LY during storage was noticed to be slower by increasing the lentil flour in respective treatments of LY. The reason for slower rate was more buffering capacity of lentil as compared to milk and the buffering capacity of lentil prevents the drop in $\mathrm{pH}$ (Zareet et al., 2012). 


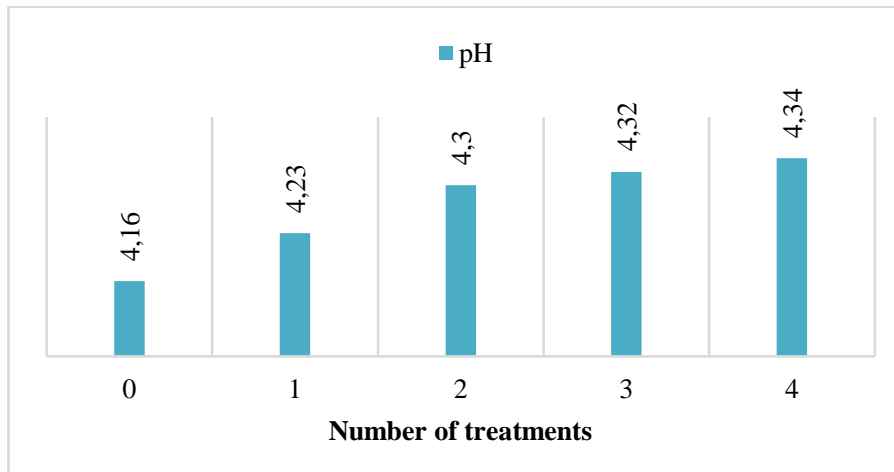

Figure $1 \mathrm{pH}$ trend during Treatments

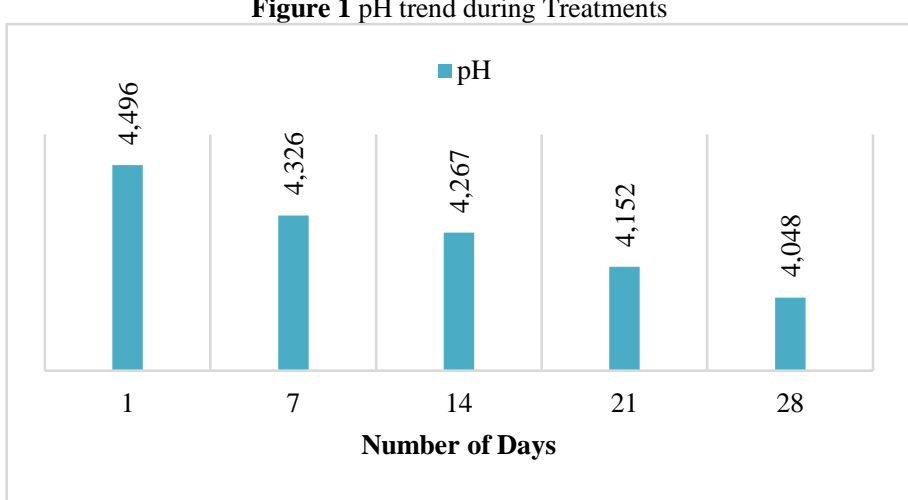

Figure 2 Trend of $\mathrm{pH}$ during Storage

\section{Effect on Acidity}

The yogurt is produced by action of lactic acid bacteria that convert lactose sugar in lactic acid during fermentation process. Data showed a highly significan $(p<0.01)$ relationship between the acidity and supplementation level of lentil four. The increasing rate of acidity was indirectly proportional to the quantity of lentil flour in respective treatments of LY. The average acidity at day 1 was $0.786 \pm 0.01,0.752 \pm 0.01,0.747 \pm 0.01,0.744 \pm 0.01$ and $0.745 \pm 0.01$ percent for $\mathrm{LY}_{0}, \mathrm{LY}_{1}, \mathrm{LY}_{2}, \mathrm{LY}_{3}$ and $\mathrm{LY}_{4}$ respectively. During storage, the acidity of $\mathrm{LY}_{0}$ sample increased relatively faster as compared to other treatments and the minimum \% acidity was recorded in $\mathrm{LY}_{4}(0.802 \pm 0.01)$ at day 7 . For whole storage period (28 days), similarly retarding effect was noticed in all samples, as maximum acidity was in $\mathrm{LY}_{0}(1.030 \pm 0.01)$ followed by $\mathrm{LY}_{1}(0.904 \pm 0.01)$ and $\mathrm{LY}_{2}(0.859 \pm 0.01)$ while at $21^{\text {st }}$ day minimum acidity was recorded in case of $\mathrm{LY}_{4}$ $(0.852 \pm 0.01)$. At the end of storage acidity was; $1.035 \pm 0.01,1.006 \pm 0.05$, $0.879 \pm 0.01,0.853 \pm 0.01$ and $0.876 \pm 0.01$ for $\mathrm{LY}_{0}, \mathrm{LY}_{1}, \mathrm{LY}_{2}, \mathrm{LY}_{3}$ and $\mathrm{LY}_{4}$ treatments respectively. Consequences of present study were in line with the results revealed by Chen (2016), Amatayakul et al. (2006) and Zare et al. (2012).

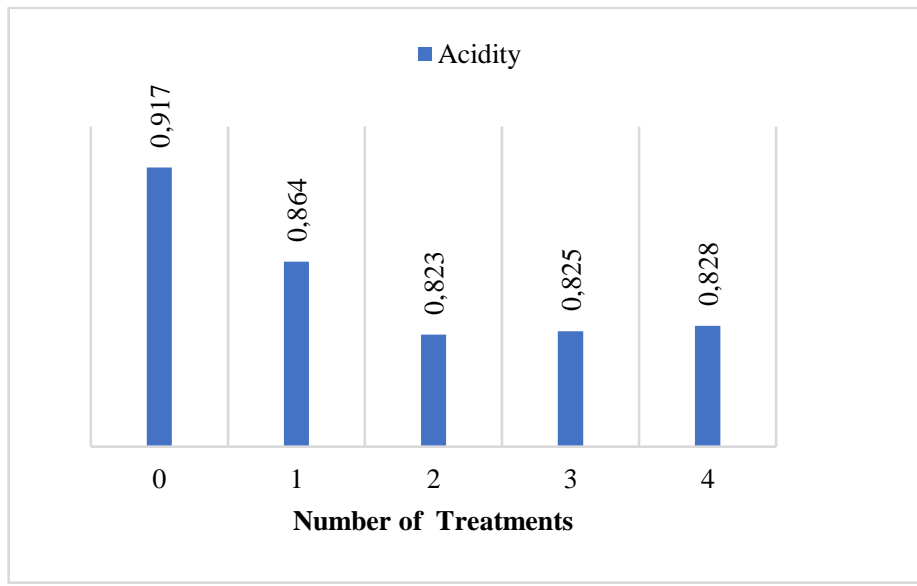

Figure 3 Effect of Treatments on acidity

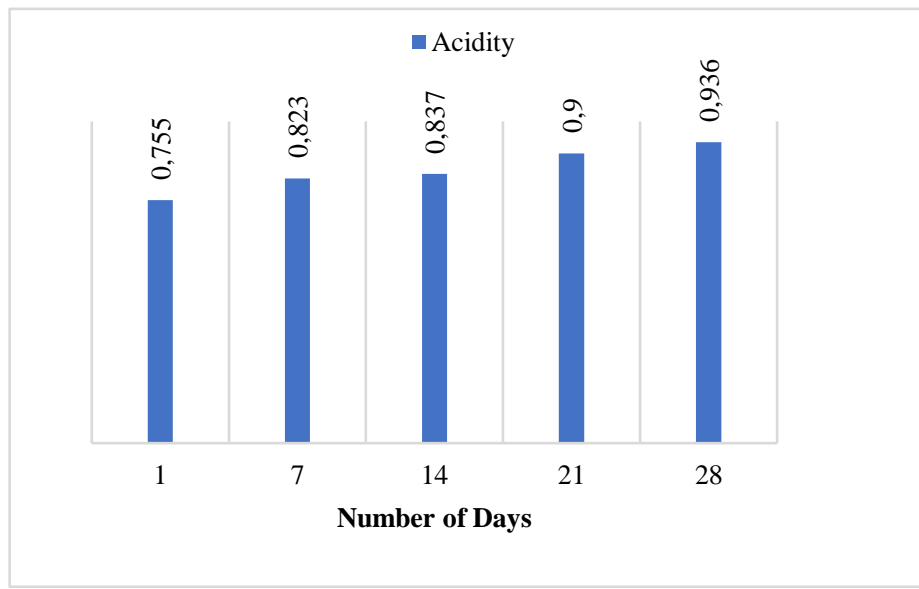

Figure 4 Effect of Storage on Acidity

\section{Effect on Viscosity}

Viscosity of yogurt can be described as thickness of sample yogurt. As the total solids increase the viscosity of final product increases but it decreases with the storage. Also the swelling ability of fine particles of flour enhances the viscosity of final yogurt. The average viscosity of LY samples decreased from $2.275 \pm 0.09$, $2.604 \pm 0.04,2.897 \pm 0.09$ and $2.371 \pm 0.09$ to $2.222 \pm 0.07,2.837 \pm 0.053 .189 \pm 0.10$ $3.147 \pm 0.05$ and $3.065 \pm 0.07$ for $\mathrm{LY}_{0}, \mathrm{LY}_{1}, \mathrm{LY}_{2}, \mathrm{LY}_{3}$ and $\mathrm{LY}_{4}$ respectively, at $7^{\text {th }}$ day of storage. It was observed that the viscosity increased as the level of supplementation in yogurt increased. $\mathrm{LY}_{4}$ had higher viscosity as compared to other samples, while $\mathrm{LY}_{0}$ exhibited minimum thickness among all the yogurt samples. With the passage of time the viscosity showed an altered trend at $14^{\text {th }}$ day viscosity of $\mathrm{LY}_{4}$ decreased suddenly to $2.040 \pm 0.07$, which was least of all. At the end of storage $\left(28^{\text {th }}\right.$ day) viscosity of yogurt was recorded as; $1.668 \pm 0.07$, $2.289 \pm 0.10,2.124 \pm 0.08,2.019 \pm 0.13$ and $1.889 \pm 0.06$ for $\mathrm{LY}_{0}, \mathrm{LY}_{1}, \mathrm{LY}_{2}, \mathrm{LY}_{3}$ and $\mathrm{LY}_{4}$ respectively, so again $\mathrm{LY}_{3}$ depicted lower viscosity among all lentil flour added yogurts but more than control $\left(\mathrm{LY}_{0}\right)$. Similar trend was observed in study of Amatayakul et al. (2006). Similarly the rate of decrease was observed to be fastest in $\mathrm{LY}_{0}$ and lowest in $\mathrm{LY}_{4}$. While $\mathrm{LY}_{1}, \mathrm{LY}_{2}$ and $\mathrm{LY}_{3}$ had relatively better viscosity. There was unusual decrease in $\mathrm{LY}_{4}$ which might be due to exceeded content of lentil flour which undesirably disrupted the structure of yogurt and caused decrease in viscosity (Zare et al., 2012)

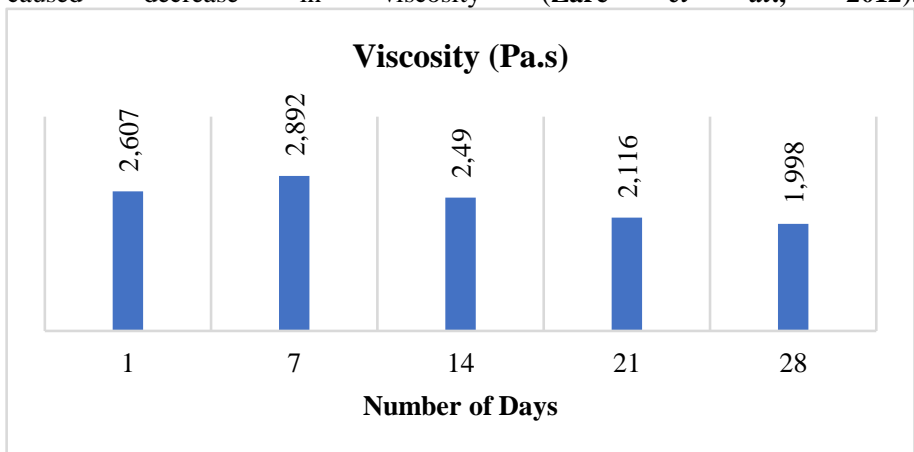

Figure 5 Effect of Treatments on viscosity 


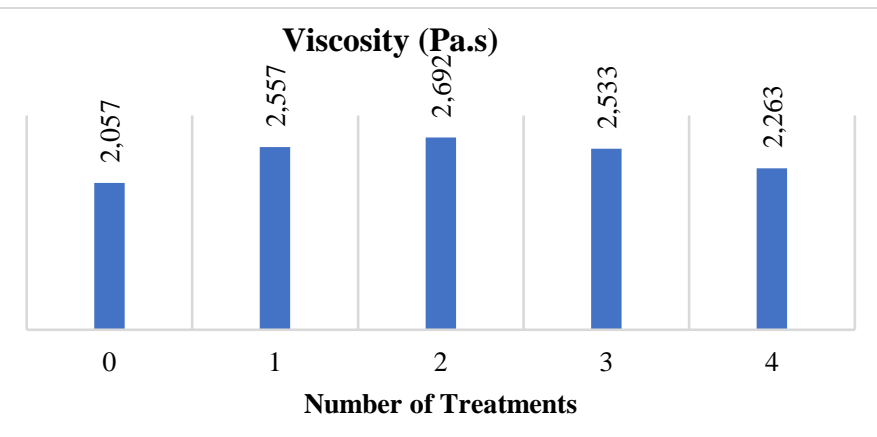

Figure 6 Effect of Storage on viscosity

\section{Effect on Synersis}

The data showed highly significant $(\mathrm{p}<0.01)$ relationship between the synersis of LF supplemented yogurt and supplementation level of lentil four. With an increase in percentage of LF for development of yogurt, the synersis of final product decreased in slower rate as compared to the control. This slower decreasing rate of synersis was directly proportional to supplementation level of lentil flour in yogurt. The data for synersis of lentil yogurt is given in figure 5 and 6. The average synersis (volume of water in $\mathrm{ml}$ per $100 \mathrm{ml}$ ) at day 1 was $3.43 \pm 0.11,5.37 \pm 0.15,5.33 \pm 0.21,2.30 \pm 0.20,1.73 \pm 0.25$ for $\mathrm{LY}_{0}, \mathrm{LY}_{1}, \mathrm{LY}_{2}, \mathrm{LY}$ and $\mathrm{LY}_{4}$ respectively. During storage minimum synersis was recorded in LY as $1.97 \pm 0.40,2.7 \pm 0.36$ and $3.47 \pm 0.40$ at $7^{\text {th }}, 14^{\text {th }}$ and $21^{\text {st }}$ day respectively. But at last day of storage ( $28^{\text {th }}$ day), minimum synersis was in $\mathrm{LY}_{0}(3.47 \pm 0.35)$ followed by $\mathrm{LY}_{4}(3.57 \pm 0.50)$ and $\mathrm{LY}_{3}(4.53 \pm 0.51)$ while $\mathrm{LY}_{2}(6.57 \pm 0.25)$ and $\mathrm{LY}$ $(8.33 \pm 0.32)$ had undesirable whey release. Consequences of present study were in line with the results revealed by Chen (2016) and Amatayakul et al. (2006).

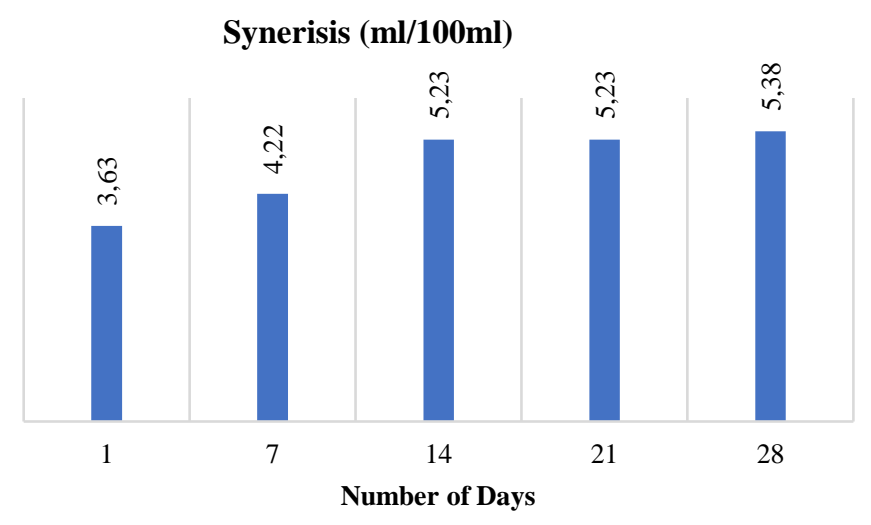

Figure 7 Effect of Treatments Synersis

\section{Synerisis $(\mathbf{m l} / 100 \mathrm{ml})$}

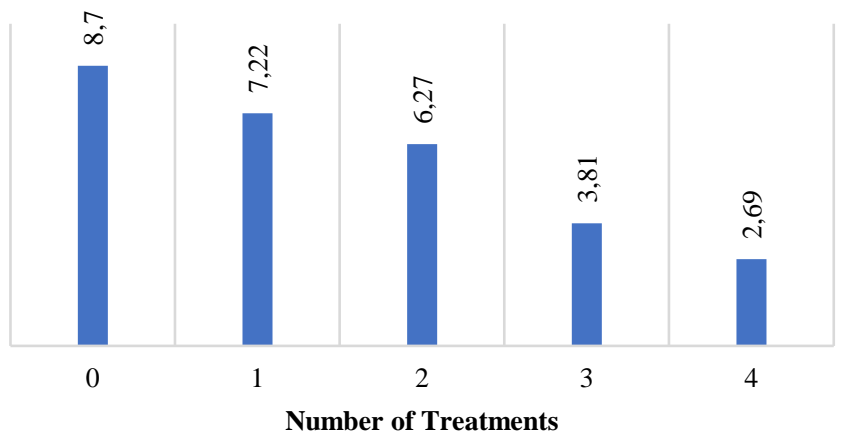

Figure 8 Effect of Storage on Synersis

Effect on Water holding capacity

Water holding capacity is an ability of food or food ingredient to bind the moisture in it. As the excessive moisture released from yogurt deteriorates the quality of yogurt. Pulses have greater WHC due to higher protein content (Singh et al., 2007), so the yogurts with greater proportion of pulses have greater WHC, as well. There were significant differences $(\mathrm{p}<0.01)$ among the yogurt samples in water holding capacity. The mean values of water holding capacity for lentil flour added yogurt samples are presented in figure 7 and 8 . Addition of lentil flour in yogurt increased the WHC of the yogurt samples as compared to control $\mathrm{LY}_{0}$ The greatest percent water holding ability $(42.67 \pm 0.58)$ was observed in yogurt sample $\mathrm{LY}_{4}$ while minimum WHC was in $\mathrm{LY}_{0}(26.27 \pm 2.08)$. During storage the WHC was slightly decreased in all treatments but the rate of decrease was faster in control and slower in the LF supplemented yogurt. The trend was $18.33 \pm 2.52$, $24.33 \pm 2.08,30.33 \pm 4.04,35.33 \pm 0.58$ and $34.33 \pm 2.08$ for $\mathrm{LY}_{0}, \mathrm{LY}_{1}, \mathrm{LY}_{2}, \mathrm{LY}_{3}$ and $\mathrm{LY}_{4}$. This result was in line to the consequences recounted for yogurt by Zare $\boldsymbol{e t}$ al. (2012) and Amatayakul et al. (2006).

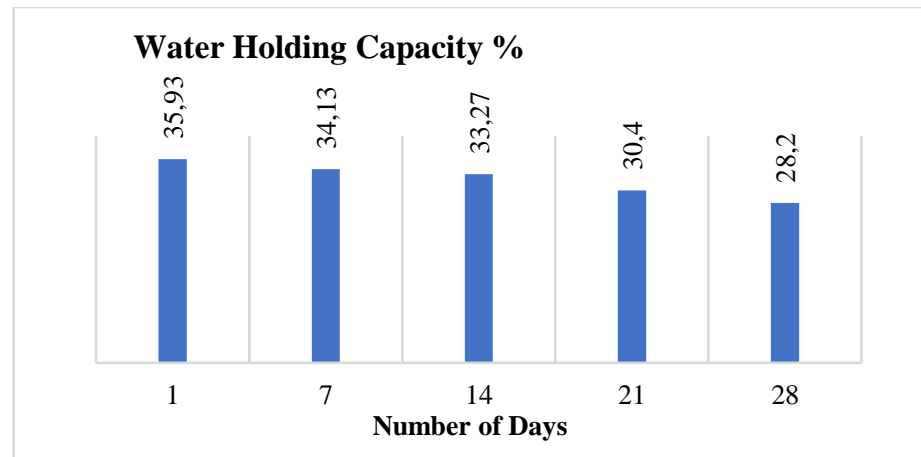

Figure 9 Effect of Treatments on Water Holding Capacity Water Holding Capacity \%

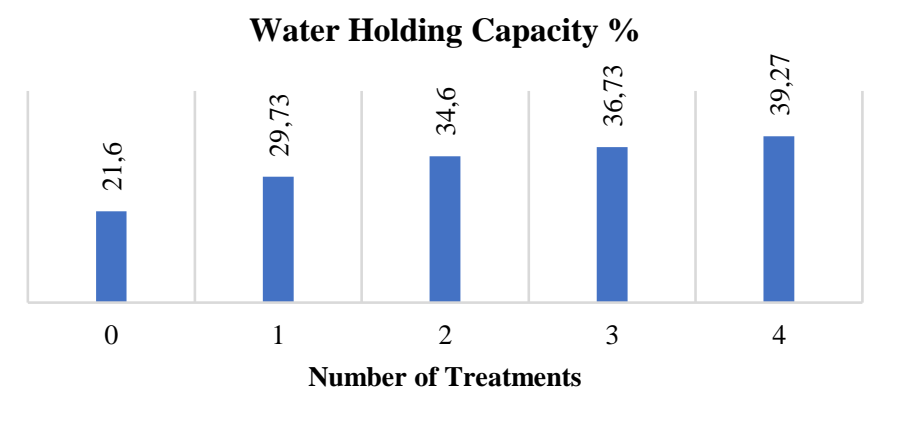

Figure 10 Effect of Treatments on Water Holding Capacity

\section{Effect on Sensory of yogurt}

Lentil flour supplemented yogurt samples were graded by trained judges using 9 point hedonic scale for selected parameters; as appearance, flavor, aroma, texture, and overall acceptability. It was witnessed that incorporation of lentil flour had highly significant effect $(\mathrm{p}<0.01)$ on appearance, significant effect $(\mathrm{p}<0.05)$ on flavor, aroma and overall acceptability but non-significant effect $(p>0.05)$ on texture of yogurt while overall acceptability descended as $\mathrm{LY}_{0}, \mathrm{LY}_{1}, \mathrm{LY}_{2}, \mathrm{LY}_{3}$ and $\mathrm{LY}_{4}$ respectively. Appearance is one of the most attracting attributes for yogurt to be approved by the consumers. Average grades for appearance influenced of different supplementation showed that appearance of yogurt was affected non-significantly; maximum scores $(8.05 \pm 0.69)$ for appearance were allotted to $\mathrm{LY}_{1}$ followed by $\mathrm{LY}_{0}(7.75 \pm 0.60)$ and $\mathrm{LY}_{2}$ while minimum $(6.9 \pm 0.77)$ to $\mathrm{LY}_{4}$ as presented in table 4.31. Average values for flavor has presented that highest grades were assigned to $\mathrm{LY}_{1}(7.85 \pm 0.71)$ while minimum to $\mathrm{LY}_{4}$ (6.60 \pm 0.88$)$. For $L Y$ texture, maximum scores $(8.05 \pm 0.73)$ were assigned for $\mathrm{LY}_{4}$ followed by $\mathrm{LY}_{3}$ and $\mathrm{LY}_{2}(7.80 \pm 1.01)$, while relatively lower scores to $\mathrm{LY}_{0}$ (7.65 \pm 0.71$)$ and $\mathrm{LY}_{1}(7.46 \pm 0.73)$. Regarding the overall acceptability, $\mathrm{LY}_{2}$ was considered to be best with assigned grades $(8.05 \pm 0.60)$, whereas $\mathrm{LY}_{4}$ at the lower level with score $(6.90 \pm 0.77)$. Keeping in view the hedonic scale grades, yogurt containing $2 \%$ of lentil flour was ranked with the best. The consequences of the current study are in line to the results of Zare et al., (2012) and Amatayakul et al. (2006). So far, it was perceived from current work that addition of lentil flour not only enhanced the nutritive value of the lentil flour supplemented yogurt but also improved the sensory characteristics of the yogurt. 
Table 3 Effect of Lentil flour addition on Sensory Evaluation

\begin{tabular}{cccccc}
\hline \multirow{2}{*}{ Treatment } & \multicolumn{5}{c}{ Sensory attributes } \\
\cline { 2 - 6 } & Appearance & Flavor & Aroma & Texture & Overall Acceptability \\
\hline $\mathrm{LY}_{0}$ & $7.70 \pm 0.59^{\mathrm{ab}}$ & $7.50 \pm 1.11^{\mathrm{ab}}$ & $7.50 \pm 1.11^{\mathrm{ab}}$ & $7.65 \pm 0.71^{\mathrm{a}}$ & $7.60 \pm 0.77^{\mathrm{ab}}$ \\
\hline $\mathrm{LY}_{1}$ & $8.05 \pm 0.60^{\mathrm{a}}$ & $7.85 \pm 0.71^{\mathrm{a}}$ & $7.85 \pm 0.71^{\mathrm{a}}$ & $7.46 \pm 0.73^{\mathrm{a}}$ & $7.75 \pm 0.59^{\mathrm{ab}}$ \\
\hline $\mathrm{LY}_{2}$ & $7.60 \pm 0.77^{\mathrm{ab}}$ & $7.10 \pm 0.84^{\mathrm{ab}}$ & $7.10 \pm 0.84^{\mathrm{ab}}$ & $7.80 \pm 1.01 \mathrm{a}^{\mathrm{a}}$ & $8.05 \pm 0.60^{\mathrm{a}}$ \\
\hline $\mathrm{LY}_{3}$ & $6.95 \pm 0.86^{\mathrm{b}}$ & $6.80 \pm 0.75^{\mathrm{ab}}$ & $6.70 \pm 0.78^{\mathrm{b}}$ & $7.85 . \pm 0.78^{\mathrm{a}}$ & $7.05 \pm 0.86^{\mathrm{b}}$ \\
\hline $\mathrm{LY}_{4}$ & $6.90 \pm 0.77^{\mathrm{b}}$ & $6.60 \pm 0.88^{\mathrm{b}}$ & $6.60 \pm 0.88^{\mathrm{b}}$ & $8.05 . \pm 0.72^{\mathrm{a}}$ & $6.90 \pm 0.77^{\mathrm{b}}$ \\
\hline
\end{tabular}

$\mathrm{LY}_{0}$ (0\% lentil), $\mathrm{LY}_{1}$ (1\% lentil), $\mathrm{LY}_{2}$ (2\%lentil), $\mathrm{LY}_{3}$ (3\% lentil) and $\mathrm{LY}_{4}$ (4\% lentil). Values with similar letters indicate non-significant relationship and dissimilar letters indicate significant relationship, among each other

\section{CONCLUSION}

The goals of current study were well attained and it was clearly evident from the results that lentil is effective supplementation source for value addition of yogurt. In the same way, the $\mathrm{LY}_{4}$ stood out the best quality as well as chemical and structural attributes among all other formulations that is evident through its prodigious potential to overcome the common physical issues of plain yogurt Results for $\mathrm{pH}$ of yogurts during incubation and during storage also supported that the developed yogurt will have relatively longer shelf life and better taste which is commonly admired by consumers. The overall sensory evaluation presented better scores for $\mathrm{LY}_{1}$ and $\mathrm{LY}_{2}$ yogurts while $\mathrm{LY}_{2}$ was nominated as best yogurt in terms of overall acceptability by panelists.

Acknowledgment: The research was carried out within the framework of state assignment 40.4149.2017/PCh, using the equipment of the center "Control and management of energy-efficient projects" of the Voronezh State University of Engineering Technologies.

\section{REFERENCES}

AGIL, R., GAGET, A., GLIWA, J., AVIS, T.J., WILLMORE, W.G., HOSSEINIAN, F. 2013. Lentils enhance probiotic growth in yogurt and provide added benefit of antioxidant protection. LWT-Food Science and Technology, 50, 45-49. https://doi.org/10.1016/j.lwt.2012.07.032.

AMATAYAKUL, T., SHERKAT, F., SHAH, N.P. 2006. Syneresis in set yogurt as affected by EPS starter cultures and levels of solids. International Journal of Dairy Technology, 59, 216-221. https://doi.org/10.1016/j.lwt.2012.07.032.

AOAC. 2012. Official Methods of Analysis of Association of Official Analytical Chemist International. 19th ed. AOAC Press, Maryland, USA. Pp: 10-94.

BOYE, J., AKSAY, S., ROUFIK, S., RIBEREAU, S., MONDOR, M., FARNWORTH, E., RAJAMOHAMED, S. 2010. Comparison of the functional properties of pea, chickpea and lentil protein concentrates processed using ultrafiltration and isoelectric precipitation techniques. Food Research International, 43,537-546. https://doi.org/10.1016/j.foodres.2009.07.021

CODINA, G.G., FRANCIUC, S.G., MIRONEASA, S. 2016. Rheological characteristics and microstructure of milk yogurt as influenced by quinoa flour addition. Journal of Food Quality, 39, 559-566. https://doi.org/10.1111/jfq.12210.

CRICHTON, G., BRYAN, J., BUCKLEY, J., MURPHY, K. 2011. Dairy consumption and metabolic syndrome: a systematic review of findings and methodological issues. Obesity Reviews, 12, 190-201. https://doi.org/10.1111/j.1467-789x.2010.00837.x

GAETKE, L.M., MCCLAIN, C.J., TOLEMAN, C.J., STUART, M.A. 2010 Yogurt protects against growth retardation in weanling rats fed diets high in phytic acid. The Journal of Nutritional Biochemistry, 21, 147 152. https://doi.org/10.1016/j.jnutbio.2008.12.005.

KAUR, R., KAUR, G., MISHRA, S.K., PANWAR, H., MISHRA, K., BRAR, G.S.. 2017. Yogurt: A nature's wonder for mankind. International Journal of Fermented Foods, 6, 57-69. https://doi.org/10.1016/i.jnutbio.2008.12.005.

KUCUKCETIN, A., EREM, F., KONAK, Ü.İ., DEMIR, M., CERTEL, M. 2012. Effect of lentil flour addition on physical and sensory properties of stirred yoghurt. Academic Food Journal, 10 , 10. https://doi.org/10.1016/j.foodres.2007.11.003.

LEE, W., LUCEY, J. 2010. Formation and physical properties of yogurt. AsianAustralasian Journal of Animal Sciences, 23, 11271136. https://doi.org/10.5713/ajas.2010.r.05.

MEILGAARD, M., CIVILE, G.V., CARR, B.T. 2007. Sensory evaluation techniques. 4th Ed. CRC Press. Boca Raton, FL, USA. 1-464.s

OZEN, A.E., KILIC, M. 2009. Improvement of physical properties of nonfat fermented milk drink by using whey protein concentrate. Journal of Texture Studies, 40, 288-299. https://doi.org/10.1111/j.1745-4603.2009.00182.x .

PENNA, A.L.B., CONVERTI, A., DE OLIVEIRA, M.N. 2006. Simultaneous effects of total solids content, milk base, heat treatment temperature and sample temperature on the rheological properties of plain stirred yogurt. Food Technology and Biotechnology, 44, 515-519.

SINGH, J., KAUR, L., MCCARTHY, O. 2007. Factors influencing the physicochemical, morphological, thermal and rheological properties of some chemically modified starches for food applications-A review. Food Hydrocolloids, 21, 1 22. https://doi.org/10.1016/j.foodhyd.2006.02.006

SODINI, I., MONTELLA, J., TONG, P.S. 2005. Physical properties of yogurt fortified with various commercial whey protein concentrates. Journal of the Science of Food and Agriculture, 85, 853-859. https://doi.org/10.1002/jsfa.2037 SOEDAMAH-MUTHU, S.S., DING, E.L., AL-DELAIMY, W.K., HU, F.B. ENGBERINK, M.F., WILLETT, W.C., GELEIJNSE, J.M. 2011. Milk and dairy consumption and incidence of cardiovascular diseases and all-cause mortality: dose-response meta-analysis of prospective cohort studies. The American Journal of Clinical Nutrition, 93, 158-171. https://doi.org/10.3945/ajen.2010.29866. STEEL, R.G.D., TORRIE, J.H., DICKEY, D.A.. 1997. Principles and procedures of statistics. A Biometrical Approach. 3rd Ed. McGraw Hill Book Co. Inc., NY. USA.

WANG, H., LIVINGSTON, K.A., FOX, C.S., MEIGS, J.B., JACQUES, P.F 2013. Yogurt consumption is associated with better diet quality and metabolic profile in American men and women. Nutrition Research, 33, 18-26. https://doi.org/10.1016/j.nutres.2012.11.009

ZARE, F. 2011. Supplementation of beverage, yogurt and probiotic fermented milk with lentil flour and pea flour and study of the microbial, physical and sensory properties of supplemented products after production during storage. $\mathrm{Ph}$ D. Thesis. Department of biosource engineering. Macdonald campus of McGill University Montreal, Canada.

ZARE, F., BOYE, J., CHAMPAGNE, C., ORSAT, V., SIMPSON, B.. 2013 Probiotic milk supplementation with pea flour: Microbial and physical properties. Food and Bioprocess Technology, 6, 1321-1331. https://doi.org/10.1007/s11947012-0828-3

ZARE, F., ORSAT, V., CHAMPAGNE, C., SIMPSON, B.K., BOYE, J.I.. 2012 Microbial and physical properties of probiotic fermented milk supplemented with lentil flour. Journal of Food Research, 1, 94-107. https://doi.org/10.5539/jfr.v1n1p94.

ZOU, Y., CHANG, S.K., GU, Y., QIAN, S.Y. 2011. Antioxidant activity and phenolic compositions of lentil (Lens culinaris var. Morton) extract and its fractions. Journal of Agricultural and Food Chemistry, 59, 2268 2276. https://doi.org/10.1021/if104640k 